\title{
COVID 19: The catalyst for digital transformation in the hospitality industry?
}

\author{
COVID 19: O catalisador para a transformação digital no sector hoteleiro?
}

\author{
Nuno António \\ NOVA Information Management School (NOVA IMS), Universidade Nova de Lisboa, Lisbon, Portugal; \\ CITUR- Universidade do Algarve, Faro, Portugal; nantonio@novaims.unl.pt \\ Paulo Rita \\ NOVA Information Management School (NOVA IMS), Universidade Nova de Lisboa, Lisbon, Portugal, \\ prita@novaims.unl.pt
}

Received: 10.02.2021; Revisions required: 17.3.2021; Accepted: 15.04.2021

\begin{abstract}
Despite its benefits related to efficiency, creating better customer experiences, increasing revenue, and supporting decision-making, until the outbreak of COVID-19 digital transformation was not on many hotels' strategic plans. However, like in many other industries, the COVID-19 physical distancing good practices and governments' restrictions acted as catalysts and promoted hotel digitalization. To this end, a questionnaire was administered to 51 hotel managers to verify if that happened in Portuguese hotels and what processes were most impacted. Results showed that $92 \%$ of the hotel managers agreed that COVID-19 promoted the digitalization of processes, with most organizations considering that online meetings and technology productivity tools are here to stay. Hotels' digitalization has the potential to generate high-efficiency gains both in public-facing operations and back-office operations. This study highlights these implications and intends to spur researchers to investigate the practical impact of these implications on business efficiency and social theory.
\end{abstract}

Keywords: Covid-19, crisis, digital transformation, hotels, pandemics.

\section{Introduction}

This manuscript has been written as a "research note" to provide very much up-to-date information based on current data regarding what hotel managers feel about digital transformation. Our main motive is to share how COVID-19 is propelling the hospitality sector to embrace digital transformation and further use it. By doing so, we aim to foster researchers to focus more attention on research in this field.

A new coronavirus causing an infectious respiratory disease was found in late 2019. The first reported cases of what became known as COVID-19 occurred in Wuhan, Hubei province, China, in late December 2019. In January 2020, the virus spread to other Chinese provinces, assisted by the Chinese New Year migration, with Wuhan being a major transport hub and rail interchange in the country. In February, this severe acute respiratory syndrome (SARS-CoV-2) spread rapidly throughout Europe, leading the World Health Organization (WHO) to consider in March this continent as being the active centre of the pandemic, which within that same month also started to impact strongly in the Americas (ECDC, 2020; WHO, 2020).

\section{Resumo}

Apesar dos benefícios relacionados com a eficiência, criação de melhores experiências para o cliente, aumento da receita e apoio na tomada de decisão, até ao aparecimento da COVID-19, a transformação digital não fazia parte dos planos estratégicos de muitos hotéis. No entanto, as boas práticas de distanciamento físico e as restrições atuaram como catalisadores e aceleraram a digitalização dos hotéis. Para avaliar o efeito da COVID-19 na transformação digital, foi administrado um questionário a 51 gestores hoteleiros para verificar se isso acontece nos hotéis portugueses e quais os processos que registam maior impacto. Os resultados mostraram que $92 \%$ dos gestores hoteleiros concordam que a COVID-19 incentivou a digitalização dos processos, sendo que a maioria considera que as reuniões online e as ferramentas de produtividade tecnológicas vieram para ficar. A digitalização dos hotéis tem o potencial de gerar ganhos altamente eficientes tanto em operações voltadas para o público quanto em operações de back-office. Este estudo destaca essas implicações e visa estimular os investigadores a estudarem o impacto prático dessas implicações na eficiência empresarial e na teoria social.

Palavras-chave: Covid-19, crise, transformação digital, hotel, pandemia.
One of the consequences of this highly contagious disease was a tsunami of hotel closures, together with a steep decline in tourism and business travel taking place across the world. This decline exerted devastating effects on the hotel industry (Filimonau, Derqui, \& Jorge Matute, 2020; Hao, Xiao, \& Chon, 2020). Due to the acute negative financial implications of this last resort deed, when an opening window was identified, decisions of reopening hotels were considered but subjected to a widespread list of cautious actions, namely, to attend public health requirements, including a myriad of safety/hygiene measures.

Notwithstanding being a medium-sized country, Portugal is a prominent tourist destination worldwide, having the oldest borders in Europe and situated in this continent's extreme south-west. Portugal was considered in 2019, for the third consecutive year, the best tourist destination in the world, receiving this award from the World Travel \& Tourism Council / WTTC (World Travel \& Tourism Council, 2020). More recently, in 2020, Portugal became the first European country to receive the seal of 'Safe Travels' by WTTC. In the last five years (20142019), Portugal's tourist flows went up by an impressive $56 \%$ 
(Turismo de Portugal, 2020). Unfortunately, due to the COVID19 pandemic that is affecting the world globally, the tourism and hospitality figures for 2020 are expected to go down significantly in a similar fashion with all other tourist destinations across the globe.

The first cases of COVID-19 in Portugal were recorded on March 2, 2020 (Direção Geral da Saúde, 2020). Despite a number of initiatives put in place, just over two weeks later, the Portuguese government had to admit the country could not contain the virus any longer and declared the state of emergency, which lasted from March 18 to May 2. Consequently, and like happened in many European countries, Portugal also had to implement lockdown measures across the country to sustain the rapid increase of cases of COVID-19. Hence, many citizens had to stay at home and work from home, and in just a few months, the landscape of work has altered dramatically, which except for COVID-19 itself, has been the radical change of 2020 (Waizenegger, McKenna, Cai, \& Bendz, 2020)

All major consulting companies recognize that the COVID-19 outbreak is accelerating digital transformation in organizations in many industries (Ernst \& Young, 2020; Hernandez, 2020; Kane, Phillips, Copulsky, \& Nanda, 2020). In fact, a report from Twilio calculated that COVID-19 accelerated companies' digital transformation strategy by an average of 6 years (Twilio, 2020). For instance, the COVID-19 pandemic triggered a digital transformation in the education sector (livari, Sharma, \& VentäOlkkonen, 2020) as well as in healthcare with a boost of telemedicine services. Many services across the board were compelled to accelerate digital transformation since many service employees had to work remotely to keep service businesses running (Bartsch, Weber, Büttgen, \& Huber, 2020).

The real question is how technology can be leveraged to allow employees to do their work more effectively and safely, and the current situation is changing how people conceive work. To face challenges and seize opportunities, employees also need digital competencies to raise productivity (Soto-Acosta, 2020). What happened in Portugal in terms of confinement was very rigorous. Hotels were closed from the end of March to at least June, so most organizations had to work remotely (if not in total, at least partially).

By the way, it should not be a surprise to see companies satisfying these much more pressing needs to increase significantly their market capitalization, such as Teladoc Health (provides videoconferencing consultations for customers with general medical professionals, dermatologists, and behavioural health specialists) and Zoom Technology (designs, produces, markets, sells, and supports broadband and dial-up modems, Voice over Internet Protocol products and services, and other communicationrelated products) being as of February 10, 2021, up 158\% and $382 \%$, respectively, in just one year (Yahoo, 2021).

Unfortunately, despite its benefits for hospitality, such as saving time, creating better customer experiences, increasing revenue, and supporting decision-making, until the outbreak of the COVID-19 pandemic, the digital transformation seemed not to be on the strategic agenda of many hotels (Alrawadieh, Alrawadieh, \& Cetin, 2020; Lam \& Law, 2019). This study was set up to find if COVID-19 brought any change to this situation and, with that, achieve a response to the following two research questions:

1. Do hotels experience an acceleration in their digital transformation process due to COVID-19?

2. What type of processes did the COVID-19 accelerate in the digitalization?

\section{Literature review}

Digital transformation is a process where digital technologies create disruptions, activating strategic responses from organizations aiming to modify their value creation paths while managing the structural changes and organizational difficulties that affect both positive and negative results of this process (Vial, 2019). The potential benefits of digitization are high. For example, when information-intensive processes are digitized, costs can be cut down to a staggering 90 per cent, and turnaround times can improve by several orders of magnitude (Shahar Markovitch, Paul Willmott, \& Paul Willmott, 2014). A digital transformation project encompasses significant challenges since it requires implementing digital capabilities to support business model transformations impacting whole organizations, particularly operational processes, resources, and internal and external users (Parviainen, Tihinen, Kääriäinen, \& Teppola, 2017).

Digital transformation has been identified as a significant hospitality trend bringing new opportunities and tremendous challenges to players in this crucial sector within the realm of the tourism industry (Lam \& Law, 2019). This movement is likely to have significant impacts due to technology developments and emerging new tourist demand, and major business areas such as marketing and operations (Salazar, 2018). In fact, despite transforming customer experiences being considered the most visible aspects of transformation, firms can achieve compelling benefits from the transformation of internal processes via process digitization, worker enablement, and performance management (Westerman, Bonnet, \& McAfee, 2014). Employees are more often working from home and using collaboration and networking tools to communicate with anyone in the company regardless of wherever they are. These tools are strong enablers of knowledge sharing and stimulate real virtualization of individual work by separating the work process from its location. The process of strategic decisionmaking is being modified by digital transformation, allowing managers to extend borderless strategic planning sessions.

However, the benefits of digital transformation are not consensual. Some authors argue that despite digital technologies' ability to ease the burdens of aesthetic and intellectual existence, digital technologies' benefits are 
overrated and driven by top Silicon Valley companies (Ossewaarde, 2019; Roth, 2019). For that reason, these authors recognize that social theory should itself evolve into a digital social theory - a useful social theory to observe a digitally transformed society.

\section{Methods}

In order to answer the research questions raised above, a survey was administered to hotel managers who participated in the XVI National Congress of the Association of Hotel Directors of Portugal (ADHP - Associação de Diretores de Hotéis de
Portugal), which took place in Évora on October 15-16, 2020. ADHP is an organization that represents Portuguese hotel managers. In most cases, hotel managers present at the congress work in hotel chains with multiple hotels and multiple brands.

The survey was conducted during a discussion panel, using the platform Sli.do (slido.com). For this reason, questions had to be kept at a low number and very concise. Hotel managers were asked to use their mobile phones/computers to answer three multiple-choice questions (see Table 1).

Table 1 - Survey questions

\begin{tabular}{|c|l|c|c|}
\hline ID & \multicolumn{1}{|c|}{ Question } & Type of answer & Choices \\
\hline 1 & $\begin{array}{l}\text { Do you consider that COVID-19 promoted the digitization of some } \\
\text { processes in your organization (ex: pre-check-in, self-check-in/out, } \\
\text { digital menus, online service reservations, among others)? }\end{array}$ & Single answer \\
\hline 2 & $\begin{array}{l}\text { In post-COVID, what do you think will be the percentage of } \\
\text { meetings, both internal (with employees) and external (with } \\
\text { customers, suppliers, and other partners), that will continue to be } \\
\text { held online? }\end{array}$ & Single answer & $-50 \%$ \\
\hline 3 & $\begin{array}{l}\text { With the appearance of covid-19, many organizations started to } \\
\text { use technological tools of productivity that they did not use before. } \\
\text { If this is the case for your organization, please indicate which tools } \\
\text { you began to use. }\end{array}$ & Multiple answers & $-100 \%$ \\
\hline
\end{tabular}

\section{Results and Discussion}

A total of 51 hotel managers answered the questionnaire. Table 2 summarizes the respondents' answers, both in frequency and percentage of each of the three questions. These results are explored below, question by question.

Table 2 - Survey summary statistics

\begin{tabular}{|c|l|c|c|}
\hline \multirow{2}{*}{ ID } & \multicolumn{1}{|c|}{ Answer } & Frequency & Percentage \\
\hline \multirow{3}{*}{1} & No & 4 & $8 \%$ \\
\cline { 2 - 4 } & Yes & 47 & $92 \%$ \\
\hline \multirow{3}{*}{2} & $0 \%$ & 2 & $4 \%$ \\
\cline { 2 - 4 } & $25 \%$ & 10 & $20 \%$ \\
\cline { 2 - 4 } & $50 \%$ & 26 & $51 \%$ \\
\cline { 2 - 4 } & $75 \%$ & 11 & $21 \%$ \\
\cline { 2 - 4 } & $100 \%$ & 2 & $4 \%$ \\
\hline \multirow{3}{*}{3} & File sharing in the "cloud" & 24 & $47 \%$ \\
\cline { 2 - 4 } & Team management & 41 & $80 \%$ \\
\cline { 2 - 4 } & Project/task management & 10 & $20 \%$ \\
\cline { 2 - 4 } & Data analysis and visualization & 13 & $25 \%$ \\
\hline
\end{tabular}

As shown in Figure 1, 92\% of hotel managers confirmed that COVID-19 promoted some of their organization's digitalization processes. Results are in line with studies on different industries, which described that the limitations and restrictions imposed by the pandemic led most organizations, independently of their area of business, to speed up their digital transformation. 
Figure 1 - Digitization processes in the organization

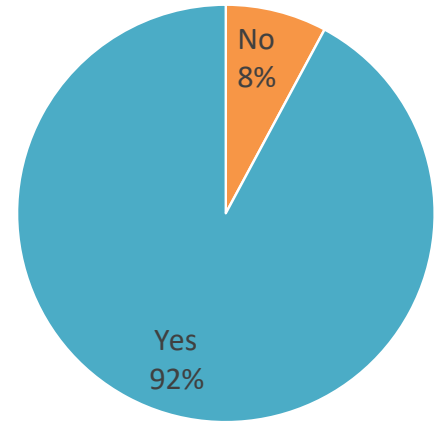

Figure 2 shows that over $75 \%$ of the respondents consider that at least half of their internal and external meetings will continue to be held online. One interesting finding is that from the four respondents who answered negatively to question one, meaning that COVID-19 did not accelerate their organization's digital transformation, only one answered that in the future, all meetings would be presential. The remaining three answered that half of their meetings should be online.

Figure 2 - Online meetings in Post-Covid 19

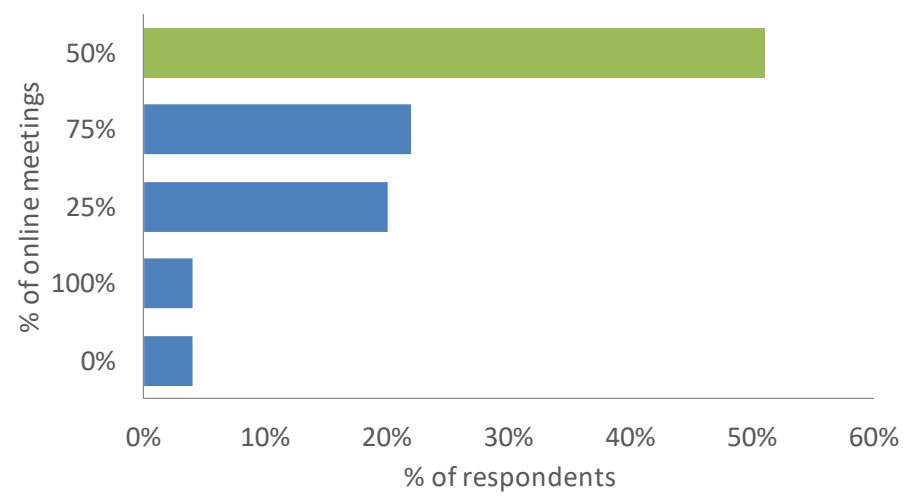

Regarding the third question on which technological tools did organizations use more due to the pandemic's consequences, as presented in Teble 2 and Figure 3, team management tools were more often used ( 41 respondents, representing $80 \%$ of the hotel managers). The second most used tool was the sharing of files via cloud platforms, with $47 \%$ of the respondents recognizing that the use of this type of tool increased in their organizations. The rise in usage of these types of tools could be related to the need for teams to work remotely, which requires files to be accessed from anywhere and have tools to manage teamwork (scheduling, online meetings, online chat, and other team management functionalities).

Figure 3 - Use of technological productivity tools during Covid 19

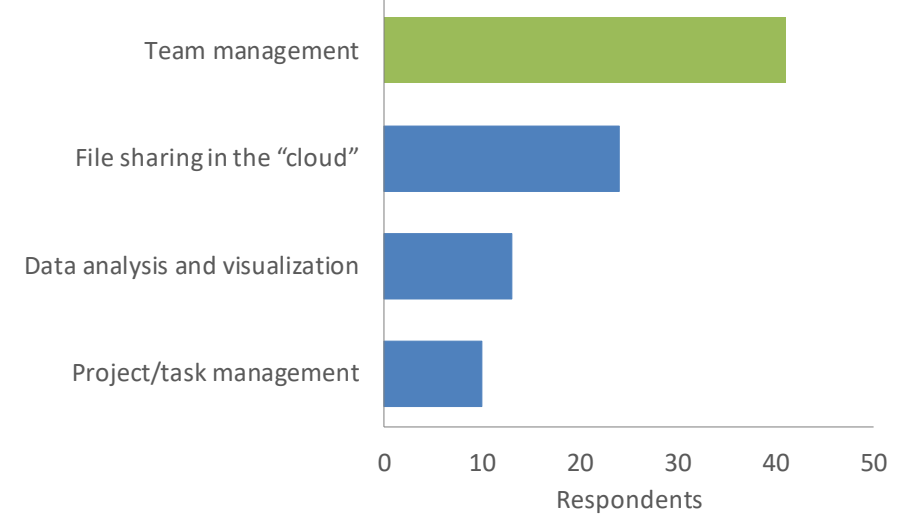

Despite the changes in booking patterns caused by the pandemic, only $25 \%$ of the respondents acknowledged having increased the use of data analysis and visualization tools. Also, only $20 \%$ of the respondents said that their organizations increased the use of project/task management tools. In this case, a discussion with hotel managers revealed that many used "Team management" tools to manage projects/tasks. 
From the 12 respondents who in question two answered that online meetings after the pandemic would be reduced to 25 per cent or less, nine answered that they increased the use of team management tools, and five increased the use of file-sharing in the cloud. This situation may indicate that hotel managers perceive that online meetings are not beneficial. Still, they accept that organizations should not stop working due to the pandemic and should digitalize their processes to continue running despite the adversities.

\section{Conclusion and implications}

This short but incisive survey shows that COVID was clearly a catalyst for digital transformation in the hospitality industry. According to the information collected from the surveyed hotel managers, digitalization seems to continue, making the old habits more likely to die out than to return.

This transformation can have multiple implications in the industry. For example, the fact that employees not related to public functions can work remotely could allow hotels to reduce office areas in order to increase their outlets or public space. In turn, working from home can be an important factor in employee retention by allowing employees to choose their work pace and better conciliate their professional and personal life. A more satisfied workforce will also be more efficient. Higher employee retention, coordinated with document digitalization and cloud storage, can also foster better knowledge management and process efficiency, improving from basic changes, like converting presential to online meetings. For example, many hotel companies' regional managers have regular face-to-face meetings. In other cases, in some companies, a hotel manager is responsible for a cluster of hotels, requiring him/her to rotate between hotels to have meetings. Converting most of these meetings to online meetings will decrease the costs of travelling and commuting to meetings and save travel time to meetings. Not to mention the positive effect on the environment. Additionally, the need to manage a workforce working remotely and sometimes in different working schedules can foster the adoption of projects and processes management tools, which in turn can also contribute to better efficiency. The general adoption of digital tools for public attendance, such as self-check-in, self-checkout, self in-room ordering, among other tools, has the potential to generate additional efficiency gains.

Following this opportune exploratory study and considering the importance of the topic to improve management and streamline processes, more studies should be done on this subject. Nonetheless, despite digital transformation's perceived benefits in the hospitality industry, there is no clear empirical evidence of that. Therefore, future studies could explore this gap and simultaneously contribute to social theory.

This study has its limitations. Considering the context where it was administered, the empirical survey was based on a short questionnaire without getting into more details on how hotels were and where they are heading. With more time available, future studies are advised to consider larger sample sizes, to go beyond a single country, as well as to achieve a sample of respondents from multiple sources (in this study was just one, despite being a relevant association of hospitality managers and directors).

\section{References}

Alrawadieh, Z., Alrawadieh, Z., \& Cetin, G. (2020). Digital transformation and revenue management: Evidence from the hotel industry. Tourism Economics.

Bartsch, S., Weber, E., Büttgen, M., \& Huber, A. (2020). Leadership matters in crisis-induced digital transformation: How to lead service employees effectively during the COVID-19 pandemic. Journal of Service Management, 32(1), 71-85. Emerald Publishing Limited.

Direção Geral da Saúde. (2020, 32-10). COVID-19-Relatório de situação. Ministério da Saúde. Retrieved February 11, 2021, from https://covid19.min-saude.pt/relatorio-de-situacao/

ECDC. (2020, October 23). Rapid Risk Assessment: Increased transmission of COVID-19 in the EU/EEA and the UK - thirteenth update. European Centre for Disease Prevention and Control. Retrieved October 24, 2020, from https://www.ecdc.europa.eu/en/publicationsdata/covid-19-risk-assessment-increased-transmission-thirteenthupdate

Ernst \& Young. (2020, June 1). COVID-19-A game changer for digital transformation, according to EY. Retrieved October 25, 2020, from https://www.ey.com/en_my/news/2020/06/covid-19-a-gamechanger-for-digital-transformation-according-to-ey

Filimonau, V., Derqui, B., \& Jorge Matute. (2020). The COVID-19 pandemic and organisational commitment of senior hotel managers. International Journal of Hospitality Management, 91, 102659. Pergamon.

Hao, F., Xiao, Q., \& Chon, K. (2020). COVID-19 and China's Hotel Industry: Impacts, a Disaster Management Framework, and PostPandemic Agenda. International Journal of Hospitality Management, 90, 102636. Pergamon.

Hernandez, J. (2020, August 17). Who or what is driving digital transformation at your organization? KPMG. Retrieved October 25, 2020, from

https://home.kpmg/xx/en/blogs/home/posts/2020/08/acceleratingdigital-transformation.html

livari, N., Sharma, S., \& Ventä-Olkkonen, L. (2020). Digital transformation of everyday life - How COVID-19 pandemic transformed the basic education of the young generation and why information management research should care? International Journal of Information Management, Impact of COVID-19 Pandemic on Information Management Research and Practice: Editorial Perspectives, 55, 102183.

Kane, G. C., Phillips, A. N., Copulsky, J., \& Nanda, R. (2020, June 8). Digital transformation through the lens of COVID-19 | Deloitte Insights. Retrieved October 25, 2020, from https://www2.deloitte.com/us/en/insights/topics/digitaltransformation/digital-transformation-COVID-19.html

Lam, C., \& Law, R. (2019). Readiness of upscale and luxury-branded hotels for digital transformation. International Journal of Hospitality Management, 79, 60-69.

Ossewaarde, M. (2019). Digital transformation and the renewal of social theory: Unpacking the new fraudulent myths and misplaced metaphors. Technological Forecasting and Social Change, 146, 24-30.

Parviainen, P., Tihinen, M., Kääriäinen, J., \& Teppola, S. (2017). Tackling the digitalization challenge: How to benefit from digitalization in practice. IISPPM - International Journal of Information Systems and Project Management, (5(1)), 63-77.

Roth, S. (2019). Digital transformation of social theory. A research update. Technological Forecasting and Social Change, 146, 88-93.

Salazar, A. (2018). Hospitality trends: Opportunities and challenges. 
Worldwide Hospitality and Tourism Themes, 10(6), 674-679. Emerald Publishing Limited.

Shahar Markovitch, Paul Willmott, \& Paul Willmott. (2014). Accelerating the digitization of business processes | McKinsey. McKinsey Digital. Retrieved February 11, 2021, from https://www.mckinsey.com/business-functions/mckinsey-digital/ourinsights/accelerating-the-digitization-of-business-processes

Soto-Acosta, P. (2020). COVID-19 Pandemic: Shifting Digital Transformation to a High-Speed Gear. Information Systems Management, 37(4), 260-266. Taylor \& Francis.

Turismo de Portugal. (2020). TravelBI by Turismo de Portugal. Travel BI - smarter decisions. Retrieved February 11, 2021, from http://travelbi.turismodeportugal.pt/en-us/Pages/Home.aspx

Twilio. (2020). Twilio-COVID-19 Digital Engagement Report. Twilio.com. Retrieved October 25, 2020, from https://www.twilio.com/covid-19-digital-engagement-report

Vial, G. (2019). Understanding digital transformation: A review and a research agenda. The Journal of Strategic Information Systems, 28(2), 118-144. North-Holland.

Waizenegger, L., McKenna, B., Cai, W., \& Bendz, T. (2020). An affordance perspective of team collaboration and enforced working from home during COVID-19. European Journal of Information Systems, 29(4), 429-442.

Westerman, G., Bonnet, D., \& McAfee, A. (2014). The nine elements of digital transformation. MIT Sloan Management Review, 55(3), 1-6.

WHO. (2020, October 20). COVID-19 weekly epidemiological update, October 20 2020. World Health Organization. Retrieved November 12, 2020, from https://apps.who.int/iris/handle/10665/336197

World Travel \& Tourism Council. (2020). World Travel Awards 2020 World Winners. World Travel Awards. Retrieved February 11, 2021, from https://www.worldtravelawards.com/winners/2020/world

Yahoo. (2021, February 10). Yahoo Finance. Yahoo. Retrieved February 10, 2021, from https://finance.yahoo.com/ 